appropriate regulatory framework governing mergers.

The content of horizontal and vertical effects that may arise in the process of implementation of merger agreements is considered and attention is focused on their possible anti-competitive effects. The practices introduced in developed countries in the field of development of fair competition and prevention of excessive concentration of markets are studied. Based on the study of the Horizontal and Vertical Merger Cases, attention is drawn to the possible impact of anticompetitive effects (both agreed and uncoordinated).

It is noted that the anti-monopoly authorities of developed countries have gained some experience in organizing procedures for analyzing merger agreements and studying their impact on the level of competition, formed specific approaches to assess anticompetitive effects that may occur in the implementation of horizontal and vertical agreements. Such practices are also of interest to Ukraine, as they avoid possible conspiracies and anti-competitive behavior.

УДК 330.341.1

DOI: $10.35340 / 2308-104 X .2021 .91-2-02$

\section{CLASSIFICATION OF TYPES OF INNOVATIONS AND METHODS OF THEIR DEVELOPMENT AND DISTRIBUTION}

\author{
ABESADZE R., \\ Doctor of Science in Economics, \\ Professor, Director of Institute, \\ BURDULI V., \\ Doctor of Science in Economics, \\ Professor, Head of Department of \\ Sectoral and Regional Economics, \\ LAZARASHVILI T. \\ Deputy Director of the Institute \\ P. Gugushvili Institute of \\ Economics of I. Javakhishvili TSU \\ (Tbilisi, Georgia)
}

\section{КЛАСИФІКАЦІЯ ВИДІВ ІННОВАЦІЙ I МЕТОДІВ ЇХ РОЗРОБКИ ТА РОЗПОВСЮДЖЕННЯ}

\author{
АБЕСАДЗЕ Р. Б., \\ Доктор економічних наук, \\ професор, директор інституту, \\ БУРДУЛІ В. Ш., \\ доктор економічних наук, \\ професор, завідувач кафедри \\ галузевої та регіональної \\ економіки, \\ ЛАЗАРАШВІЛІ Т. Н., \\ заступник директора інституту
} П. Гугушвілі Інститут економіки ТДУ ім. І. Джавахішвілі (Тбілісі, Грузія)

У роботі класифікуються види інновацій та систематизуються шляхи їх розвитку та розповсюдження. Види інновацій класифікуються в контексті критеріїв значущості, ступеня новизни, предмета та обсягу, за розробником, за типом інновації, за місцем у системі підприємства та іншими критеріями, а потім детально описуються. Систематизуються та пояснюються методи розробки та інструменти розповсюдження інновацій.

Ключові слова: види інновацій, основні, удосконалюючі та псевдоінновації, інновації на виробництві, технологічні інновації, методи розробки інновацій, інструменти розповсюдження інновацій.

В работе классифицируются виды инноваций и систематизируются способы их разработки и распространения. Типы инноваций классифицируются в контексте критериев значимости, 
степени новизны, предмета и объема, по разработчикам, по типу инноваций, по месту в системе предприятия и другим критериям, а затем подробно описываются. Систематизируются и разъясняются методы разработки и инструменты распространения инноваций.

Ключевые слова: типы инноваций, базовые, улучшающие и псевдоинновации, продуктовые инновации, процессные инновации, методы разработки инноваций, инструменты распространения инноваций.

The work classifies types of innovations and systematizes the ways of their development and dissemination. Types of innovations are classified in the context of the criteria of significance, degree of novelty, subject and scope, by developer, by type of innovation, by place in the enterprise system and other criteria, and then they are described in detail. The methods of development and tools for disseminating innovations are systematized and explained.

Keywords: types of innovations, basic, improving and pseudoinnovations, proproduct innovations, process innovations, methods of developing innovations, tools for disseminating innovations.

Statement of the problem and the purpose of the study. In order to investigate the problems of the diffusion of innovations, it is first necessary to study modern views on the classification of types of innovations and the systematization of the methods of their development and dissemination. Investigating these issues, we set the goal of compiling a modern classification of types of innovations and characterizing these types, as well as systematizing and briefly discussing the ways of their development and dissemination.

Statement of the main research material. Classification of innovations. There are many variants of the classification of innovations in the economic literature $[4 ; 5 ; 6 ; 7 ; 8 ; 9 ; 10]$. Based on their study and based on modern ideas about the nature of innovation, we have compiled a more modern classification.

According to the latest concepts, innovations should be classified according to the following features (criteria): a) by importance (by the level of impact on the economy); b) according to the degree of novelty for the market or enterprise and in relation to its predecessor (by succession); c) by developer (source of development); d) by field of application or type of innovation; e) by the subject and scope of innovation; $f$ ) on the basis (scale) of prevalence; $g$ ) in place in the system of an enterprise, firm, organization; $h$ ) by the form of innovation; i) by the elements of the value chain; j) due to the occurrence; $k$ ) by the nature of satisfaction of needs; l) by the type of effect obtained as a result of the introduction of innovations.

Let's consider the types of innovations in the context of some of these features (criteria).

a) In terms of importance (or the level of impact on the economy), basic (radical), improving and pseudo-innovations are distinguished.

Basic (radical) innovations can represent a new or radically improved product or service, as well as a new or radically improved manufacturing technology. Otherwise, these innovations are called radical. Basic innovations are based on scientific discoveries and major inventions of new generations of technique and technology; their accumulation leads to a new technological level.

Improving innovations are innovations that provide a significant improvement in the baseline. Improving innovations provide for the implementation of medium-level inventions and serve as the basis for 
the creation of new models and modifications of this generation of technology, replacing outdated models with more efficient ones.

Pseudo-innovations (in some sources they are called modification or private), which are the most widespread, make it possible to achieve their maximum efficiency by insignificantly advancing basic and improving innovations. At the same time, the sales market and the sphere of using innovations are expanding.

b) Innovation according to the degree of novelty for the market or enterprise and in relation to its predecessor (by succession). According to the degree of novelty for the market, innovations that are new for the industry in the world, new for the industry in the country and new for a given enterprise are distinguished. In relation to its predecessor (by succession), Replacing, rationalizing, expanding, canceling, recurrent, opening, retrovings, innovations are distinguished.

The degree of novelty is also determined on the basis of a new discovery or on the basis of a new method of application to longdiscovered phenomena (retrovings).

Expanding innovation aims to use the principles and methods of basic innovation in other economic areas.

Substitutional (replacing) innovations are designed to perform operations in a different, more efficient way. They involve the complete replacement of the obsolete tool, thereby ensuring a more efficient performance of the corresponding function.

Canceling - exclude the performance of some operation, release of some product and do not replace them with new ones.

Returnable (recurrent) - when, after some use of the innovation, its inconsistency or discrepancy with the new conditions is discovered and one has to return to its predecessor.

Openers are creators that do not have comparable functional predecessors.

Retrovings are innovations that reproduce at the modern level, seemingly exhausted methods, devices, materials.

c) According to the developer (source of innovation development). An innovation can be developed by an enterprise or an external source (for more details, see the section "Methods for the development and dissemination of innovations" of this subsection).

d) According to the field of application and type of innovation, there are material and technical (equipment, technology, raw materials), social innovations (organizational and managerial, legal, pedagogical), economic, environmental, in the field of green economy, in the field of circular economy and utilization, marketing, information and communication (now mostly digital), etc.

The greatest application in practice is found in technological innovations - the product of innovation in the form of new products and the process of introducing new technologies, equipment and materials. Organizational and managerial innovations include the development and implementation of a new organizational structure for enterprise management, new organizational structures, forms of work organization, development and control of decisions; to economic - the use of previously unapplied systems and forms of remuneration, methods of managing production costs, new material incentives; to marketing - the development of new markets and ways of promotion; to social - the use of previously unused methods of labor motivation; to environmental the use of new technologies - the implementation of new technologies 
in the field of environmental protection; to information and communication - the use of new information and communication and other digital technologies (here we note that the previously encountered definition of "information and telecommunication technologies" is not all-encompassing, "tele" in Latin means "far away", but information and communication technologies are also used at close distances, for example, equipping machine tools with numerical control), to legal changes in legislation, to pedagogical - new methods of teaching and upbringing.

e) According to the subject and scope of application, product innovations (new products, including labor tools, and materials) and process innovations (technologies, organizational production processes, management processes) are distinguished, i.e. innovations in the form of a product and innovations in the form of operations. In addition, some sources highlight market innovations (innovations that open up new areas of application of the product, innovations that allow the product to be implemented in new markets).

Product innovation encompasses the introduction of technologically new or improved products. A technologically new product (radical product innovation) is a product whose technological characteristics (functional features, design, additional operations, as well as the composition of the materials and components used) or the intended use are fundamentally new or significantly differ from similar characteristics and use of previously produced products. Such innovations can be based on fundamentally new technologies or on a combination of existing technologies in their new application (including the use of research and development results). A technologically improved product is an existing product, the quality or cost characteristics of which have been significantly improved through the use of more efficient components and materials, partial changes in one or a number of technical subsystems (for complex products) [7; 9].

Product innovations are decisive as ways and means of satisfying social needs, primarily material ones. A significant part of product innovations is made up of means of labor. Product innovations have become decisive in relation to others, and for the reason that many organizational, managerial, socio-economic innovations are due to the emergence of new types of products and the conditions for their consumption. Moreover, the very practical implementation of such innovations mainly depends on the level of product innovations and the rate of their spread. For example, the introduction of an automated control system (organizational and managerial innovation) or the treatment of reservoirs (environmental innovation) is determined by the level of development of technical means - computers, treatment facilities, etc. (product innovations). Product innovations, depending on their area of application, are subdivided into products for industrial, consumer and other purposes (scientific, defense, sports, environmental). All these innovations regardless of their purpose, are industrial products [8].

Process innovation is the development of new or significantly improved production methods, changes in equipment or production organization, or both. Process innovation includes the development and implementation of technologically new or technologically significantly improved production methods, including methods of transferring products (production methods of logistics, supply of goods and 
services, as well as in ancillary activities). Innovations of this kind can be based on the introduction of new production equipment and / or software, new technologies, significant changes in the production process or their combination. Such innovations are aimed, as a rule, at reducing production costs or activities for the transfer of products, services per unit of production, improving the quality, production efficiency or transfer of products already existing in the organization, but can also be intended for the production and transfer of technologically new products, services, which cannot be produced or supplied using the equipment available or the manufacturing methods used.

From the above, it is clear that one and the same new technology in one case or another can be both product and process innovation. For example, the release of a new (innovative) machine tool by an enterprise is a product innovation, and the introduction of such a machine into the production process at another enterprise is a process innovation.

f) On the basis (criterion) of prevalence (scale), one can distinguish single and diffuse innovations, in other words, carried out at one object, and repetitive ones, spread over many objects.

And most importantly, used only in one specific industry and distributed in many industries (for example, information and communication innovations).

g) According to the place in the system of the enterprise, firms or organizations, distinguishd innovations at the entrance of the enterprise (changes in the selection and use of raw materials, stuffs, machinery and equipment, information, etc.), innovations at the exit of the enterprise (products, services, technologies, information, etc.), innovation of the systemic structure of the enterprise (management, production, technological), i.e., innovation of the structure of the enterprise as a system that includes individual elements and mutual relationships between them.

h) By the form of innovation - discovery, invention, rationalization proposal, know-how, trademarks and brands, new documents, designs, structures, methods.

i) According to the elements of the value chain, resource innovations, innovations of a finished product, innovations of an object, innovations in service and subsequent maintenance, innovations in recycling are distinguished.

j) By reason of occurrence, reactive (adaptive) and strategic innovations are distinguished.

Reactive (adaptive) innovation is innovation that ensures the survival of the firm as a reaction to innovations carried out by a competitor, allowing the company to continue to fight in the market; Strategic innovation is an innovation that is proactive in order to gain competitive advantages in the future. Both types of these innovations are aimed at increasing the competitiveness of a product or service.

k) According to the nature of the needs being met, innovations are subdivided into those oriented towards meeting existing needs (meeting existing needs in a different way; meeting existing needs more effectively) and oriented towards meeting new needs (creating new needs).

I) By the type of effect obtained as a result of the introduction of innovations - scientific and technical, social, environmental, economic (commercial), integral. 
The above classification of innovations can be used not only for statistical purposes, which is especially necessary for solving the problems of this article, but also will allow enterprises to position products in a competitive market, assess the level of their own competitiveness, elaborate a development strategy, and justify measures to improve management. It is also necessary to ensure adequate support from the state for the introduction of innovations at the country's enterprises. That is, it has a considerable practical significance.

Ways to develop and disseminate innovations. To a certain extent, this issue was covered by us in some articles $[1 ; 3]$. Let us outline this issue briefly and systematically, based on the above classification of types of innovations.

Ways to develop innovations. As noted, according to the development criterion, an innovation can be developed by an enterprise or an external source, but most often, especially basic and improving innovations, are developed by external specialized entities.

Basic subject and process innovations (first of all, new production technologies) are developed either at enterprises producing modern production technologies, or in specialized design bureaus, which can also be part of large enterprises, for example, in TNCs.

Basic product innovations can be developed both within large enterprises and in small and medium-sized enterprises creating an innovative product, including in so-called innovative enterprises.

Improving innovations of the system structure of the enterprise and improving innovations at the exit from the enterprise are most often developed by the enterprise, with the acquisition for this purpose of patent licenses, know-how, technological documentation, etc., or on the basis of attracting representatives of specialized organizations for their implementation.

In addition, improving and modifying (pseudo-) innovations are created in innovation laboratories, in industrial innovation laboratories, in innovation centers and in small enterprises created within innovation clusters or technology parks.

In all developed countries, most of the innovation occurs in the business sector, but in many of these countries there are also such enterprises developing an innovative product, the creation of which is fully or partially funded by the state.

In most developed countries, universities and other research centers are the core of national innovation systems, in which, in addition to fundamental research, applied research is also carried out, some of which are embodied in innovation.

Ways to disseminate innovation. Even in the case of internal (within an enterprise or organization) development of innovations (basic, improving, modification), the conditions for their dissemination often require the purchase of patent licenses, technological documentation, etc.). Funding in this case is independent, but state support is not excluded. TNCs and other large corporations independently implement their innovation strategy, although sometimes they do not shy away from government support or the involvement of specialized partners (especially when implementing process innovations).

However, which is quite natural, in most medium and small enterprises and organizations (with the exception of specialized innovative enterprises), innovations are spread by purchasing basic 
(including in the form of "turnkey contracts") and in different types (equipment, documentation, licenses, advisory services, etc.) improving and modifying innovations, often with the involvement of specialists to facilitate their implementation.

Naturally, the main way of promoting innovations in production (spreading innovations in production) is borrowing (most often imports) of both basic and improving innovations, product and process innovations at each stage of their promotion (special scientific research, direct development, implementation).

We list the main modern mechanisms that exist in developed countries for the promotion (diffusion) of innovations in production $[1 ; 2$; 3].

Ensuring innovation policy of the state: a) government organizations that determine the innovation policy of the state, ministries, departments, agencies, foundations and other regulatory and funding agencies; in Georgia, following the example of developed countries, the government as a whole, the Ministry of Economy and Sustainable Development, the Ministry of Regional Development and Infrastructure, the Ministry of Agriculture are primarily concerned with innovation policy issues; the Georgian Agency for Innovation and Technology, the Agency for Rural Development has been created and is actively working; b) strategy and programs of innovation policy; in this aspect, in the process of spreading innovations in developed countries, various programs play an important role in the financing of which the state also participates, for example, programs for organizing innovative start-ups; c) regulatory and legal framework in the field of development and stimulation of innovation, including provisions regulating the relationship between science, business and the state; in this regard, Georgia has adopted the Law of Georgia on Innovations, but other laws also contain provisions regulating this activity.

Production of innovations: a) business sector (companies producing an innovative product - innovation-developing subdivisions in large corporations, small and medium-sized enterprises creating an innovative product); b) enterprises developing an innovative product, the creation of which was partially or fully financed by the state (for example, according to the principle of state venture).

Research sector (universities and research institutes). In developed countries, universities and research institutes pay great attention to scientific developments focused on innovative research.

Technology organizations and other elements of innovation infrastructure (technology parks, business incubators, business accelerators, technology commercialization and transfer centers, innovation laboratories, etc.). All these structures should facilitate the identification and implementation in production of both domestic (which are few in a small country) and, in particular, imported new production technologies. In fact, in addition to the "technology transfer center", other elements of the innovation infrastructure are directly or indirectly involved in the transfer. For example, the task of business accelerators is usually to support the absorption of technologies (including investment) by innovative startups, which can also be viewed as an element of the technology transfer process.

The system of interaction with the international innovation environment, that is, the relationship with foreign partners in innovation, both in the field of supplying (transfer) of new technologies to the 
country, and in the field of joint innovative developments, including through the creation of venture innovative enterprises in conjunction with foreign partners.

The block of financing innovative activities: a) state financing of innovative activities; $b$ ) financing of innovation activities by the business sector; in many countries, financial and industrial groups play an important role in this aspect; c) public-private partnership in the field of financing innovative activities.

Innovative clusters. Unlike traditional industrial clusters, innovative clusters represent a system of close relationships not only between firms, their suppliers and customers, but also knowledge institutions, including large research centers and universities, innovation divisions of large corporations, innovative enterprises, etc. Through the system of interconnections between the specified objects, the developed innovations are spread not only within the cluster, but also outside of its activity.

Innovative clusters are at the national level and at the regional level. It should be taken into account that clusters, regardless of their territorial size, are formed mainly within a certain industry specialization. Even the innovative enterprises of the famous California Silicon Valley are mostly specialized in the field of information and communication technologies. Within the region of the first level of NUTS, of course, there can be several clusters related to different industries, for example, in Finland there are at least two clusters at the national level. However, the majority of innovation clusters specialized in a certain type of activity in the EU countries (of which there are already more than 2 thousand) are formed within territorial units of a lower NUTS level (for details, see the article indicated in the footnote [2].

Conclusions. Based on modern concepts, we have compiled a classification of innovations in the context of a number of criteria for their identification, as well as systematized and characterized the ways of developing and disseminating innovations.

The types of innovations are given and highlighted in the context of the following criteria: by importance (basic, improving and pseudoinnovations); by the degree of novelty for the market or enterprise; by the developer (external sources or by the forces of the enterprise); by field of application or type of innovation (material and technical or technological; social, including organizational, economic, legal and pedagogical; environmental; in the field of green economy; information and communication or digital; in the field of circular economy, etc.); by subject and scope (product and process); by the criterion of prevalence (single and diffuse, that is, distributed in many industries); in place in the enterprise system (innovations at the entrance to the enterprise, innovations in the system structure of the enterprise, innovations at the exit of the enterprise), etc.

Further, the ways of developing innovations are systematized. According to the development criterion, an innovation can be developed by an enterprise or an external source, but most often, especially basic and improving innovations, are developed by external specialized entities, which are systematized and described in the corresponding paragraph (Methods for developing innovations) of the first section.

Methods of diffusion of innovations are systematized and characterized in detail. Even in the case of internal (within an enterprise 
or organization) development of innovations (basic, improving, modification), the conditions for their dissemination often require the purchase of patent licenses, technological documentation, etc.). However, which is quite natural, in most medium and small enterprises and organizations (with the exception of specialized innovative enterprises), innovations are spread by purchasing basic (including in the form of "turnkey contracts") and in different types (equipment, documentation, licenses, advisory services, etc.) improving and modifying innovations, often with the involvement of specialists to facilitate their implementation.

Naturally, the main way of promoting innovations in production (spreading innovations in production) is borrowing (most often imports) of both basic and improving innovations, product and process innovations at each stage of their promotion (special scientific research, direct development, implementation).

At the end of the article, the main modern mechanisms existing in developed countries for the promotion (spread) of innovations in production are given and characterized.

Generalization and systematization of the classification features of innovations, methods of their development and distribution is of significant practical importance, since it has the potential ability to give a detailed idea of the characteristics of a progressive innovation, makes it possible to identify the characteristics of innovations, successfully manage innovation, see the available reserves, select the most rational options for management decisions. In particular, it is necessary to provide adequate support from the state for the introduction of innovations at the country's enterprises.

\section{Література:}

1. Abesadze R, Burduli V. Modern State and Priorities for Forming the National Innovation System of Georgia. International Journal of New Economics and Social Sciences № 1(9)2019. P. 12-29. URL: https://ijoness.com DOI: 10.5604/01.3001.0013.3013.

2. Abesadze R., Burduli V. National, Regional and Supranational Coordination of the Regional Innovation Policy in the EU Countries. International Journal of New Economics and Social Sciences. № 1(7)2018. P. 11-38. URL: https://ijoness.com/resources/html/article/detail s?id=175031

3. Абесадзе Р., Бурдули В. Современное состояние и приоритеты формирования национальной инновационной системы Грузии. Ж.: Ekonomisti, 2017. № 1 (Volume XII).
4. Виды
инноваций
u $\quad u x$
классификация.
URL:

http://www.grandars.ru/student/menedzhment/vidy-innovaciy.html.

5. Гонаренко О. И. Менеджмент инвестиций и инноваций. М.: KHOPYC, 2011. С. 68.

6. Классификации инноваций в современной экономике. Предположительно 2016 г. URL: https://euroasiascience.ru/ekonomicheskienauki/\%D0\%BA\%D0\%BB\%D0\%B0\%D1\%81\%D1\%81\%D0\%B8\%D1\%84\%D0\% B8\%D0\%BA\%D0\%B0\%D1\%86\%D0\%B8\%D0\%B8\%D0\%B8\%D0\%BD\%D0\%B D\%D0\%BE\%D0\%B2\%D0\%B0\%D1\%86\%D0\%B8\%D0\%B9-\%D0\%B2\%D1\%81\%D0\%BE\%D0\%B2\%D1\%80\%D0\%B5\%D0\%BC\%D0\%B5\%D0\%BD\%D $\underline{\mathrm{O} \% \mathrm{BD} / .}$. 
7. Классификация и виды инноваций. URL: http://www.grandars.ru/student/menedzhment/vidy-innovaciy.html.

8. Мухамедъяров А. Инновационный менеджмент. 1.3. Классификация инноваций. URL: https://econ.wikireading.ru/21827

9. Пригожин А. И. Нововведение: стимулы и перспективы. М.: Политиздат, 1998.

10. Тема 3. Классификация (типизация) инноваций. URL: https://moodle.kstu.ru/mod/book/view.php?id=15433\&forceview=1.

References:

1. Abesadze R, Burduli V. Modern State and Priorities for Forming the National Innovation System of Georgia. International Journal of New Economics and Social Sciences № 1(9)2019. P. 12-29. URL: https://ijoness.com DOI: 10.5604/01.3001.0013.3013.

2. Abesadze R., Burduli V. National, Regional and Supranational Coordination of the Regional Innovation Policy in the EU Countries. International Journal of New Economics and Social Sciences № 1(7)2018. P. 11-38. URL: https://ijoness.com/resources/html/article/details?id=175 031

3. Abesadze R., Burduli V. Sovremennoe sostoyanie i prioritety formirovaniya natsional'noy innovatsionnoy sistemy Gruzii. Zh.: Ekonomisti, 2017, № 1 (Volume Khll).

4. Vidy innovatsiy i ikh klassifikatsiya. URL: http://www.grandars.ru/student/menedzhment/vidy-innovaciy.html

5. Gonarenko O. I. Menedzhment investitsiy i innovatsiy. M.: KNORUS, 2011. S. 68, 159.

6. Klassifikatsii innovatsiy $v$ sovremennoy ekonomike. Predpolozhitel'no 2016 g. URL: https://euroasiascience.ru/ekonomichesk ienauki/\%D0\%BA\%D0\%BB\%D0\%BO\%D1\%81\%D1\%81\%D0\%B8\%D1\%84\%D0 \%B8\%D0\%BA\%D0\%B0\%D1\%86\%D0\%B8\%D0\%B8-

\%D0\%B8\%D0\%BD\%D0\%BD\%D0\%BE\%D0\%B2\%D0\%B0\%D1\%86\%D0\%B8\% D0\%B9-\%D0\%B2-

\%D1\%81\%D0\%BE\%D0\%B2\%D1\%80\%D0\%B5\%D0\%BC\%D0\%B5\%D0\%BD\%D $\mathrm{O} \% \mathrm{BD} /$.

7. Klassifikatsiya i vidy innovatsiy. URL: http://www.grandars.ru/student/menedzhment/vidy-innovaciy.html.

8. Mukhamed"yarov A. Innovatsionnyy menedzhment. 1.3. Klassifikatsiya innovatsiy. URL: https://econ.wikireading.ru/21827

9. Prigozhin A. I. Novovvedenie: stimuly i perspektivy. M.: Politizdat, 1998.

10. Tema 3. Klassifikatsiya (tipizatsiya) innovatsiy. URL: https://moodle.kstu.ru/mod/book/view.php?id=15433\&forceview=1 